\title{
Patterns of Giving in South Africa
}

\author{
David Everatt, ${ }^{1}$ Adam Habib, ${ }^{2}$ Brij Maharaj, ${ }^{3}$ and Annsilla Nyar ${ }^{4,5}$
}

This paper reflects on the results of a national quantitative survey on giving in South Africa. It explores the extent and character of giving; who gives, to whom, with what intention? The survey results revealed that South Africa is richly resourced with a diverse and multicultural spectrum of giving behaviors, which are commonplace in everyday life. The spectrum of giving behaviors is so diverse in shape and form that it contradicts many of the basic assumptions of the philanthropic literature, which locate the act of giving primarily in the domain of the wealthy and powerful.

KEY WORDS: giving; philanthropy; poverty alleviation; development; South Africa.

\section{INTRODUCTION}

This paper investigates giving among South Africans. It explores its extent and character; who gives, to whom, with what intention? The paper reflects on the results of a national survey, the first such quantitative investigation in South Africa, commissioned by the Centre for Civil Society (CCS) at the University of KwaZulu-Natal, as part of its State of Giving project (www.ukzn.ac.za/css). The survey was based on a national random sample of 3,000 respondents, yielding an error bar of $1.8 \%$. The sample was stratified by race, province, and spatial (rural/urban) location, based on Census 2001. The results are representative of all South Africans aged 18 and above, in all parts of the country, including formal and informal dwellings. Unlike many surveys, the rural component of the sample

\footnotetext{
${ }^{1}$ Strategy and Tactics, Johannesburg, South Africa.

${ }^{2}$ Democracy and Governance, Human Science Research Council, Pretoria, South Africa.

${ }^{3}$ Department of Geography, University of KwaZulu-Natal, Durban, South Africa.

${ }^{4}$ Centre for Civil Society, University of KwaZulu-Natal, Durban, South Africa.

${ }^{5}$ Correspondence should be directed to Adam Habib, Executive Director, Democracy and Governance, Human Science Research Council, Pretoria, South Africa; e-mail: ahabib@hsrc.ac.za
} 
(commonly the most expensive for logistical reasons) was large and did not require heavy weighting (where a small number of respondents have to represent the views of a far larger community).

Randomness was built into the selection of starting points (from which fieldworkers begin their work) — every fifth dwelling was selected, after a randomly selected starting point had been identified — and into the selection of respondents, where the birthday rule was applied. (That is, a household roster was completed, all those aged 18 and above were listed, and the householder whose birthday came next was identified as the respondent.) Three callbacks were undertaken to interview the selected respondent; if s/he was unavailable, the household was substituted. Some problems of access were encountered in predominantly White suburbs, where fieldworkers battled to get past high gates and intercoms as well as suspicions that the survey was yet another election poll (the survey fieldwork occurred in the run-up to South Africa's third democratic general election). Nevertheless, the results do provide the first comprehensive overview of giving in South Africa.

\section{REFLECTIONS, ASSUMPTIONS, AND INVESTIGATIVE QUESTIONS}

Any macro-study of giving in current day South Africa has to confront the problem of a dearth of academic literature on the subject. This is not to suggest that nothing has been written on the issue. Indeed, there is a sizable literature on giving in South Africa (Bezuidenhout et al., 2003; Du Toit, 2001; Rockey, 2000). But, like in many other parts of the world, this literature is largely descriptive, focused on either the philanthropic acts of financially successful individuals and families, or the patterns of support and behavior within particular religious and/or ethnic communities. In the corporate social responsibility arena, the literature tends to take a practitioner-oriented form, providing advice and recommendations on how to professionalize giving and support by corporate business. Both sets of literature are useful for providing empirical insights into processes of giving in particular contexts, but they do not naturally lend themselves to assisting the development of theoretical levers required for any comprehensive research into giving in South Africa. For assistance in this regard, a review of the academic literature on philanthropy developed in other parts of the world is required.

Much of the literature on philanthropy and giving originates from scholars located in the United States and Western Europe. This is not only a result of the skewed character of the global economy, but also a consequence of the fact that a significant part of professionalized giving, in the form of corporates and foundations, has been concentrated on these continents. This near monopoly of philanthropic focus, however, has begun to change in the last two decades. In part, this has to do with the increasing importance of the Asian economy and the resultant emergence of a significant number of private trusts and foundations 
that are making important contributions to advancing the social development agenda in this part of the world (Estes, 1998). The phenomenon, however, is not limited to Asia. As Salamon (1995, p. 5) points out, "a global 'associational revolution' appears to be underway around the world... a striking upsurge of organized, private, voluntary activity in virtually every corner of the globe."

Notwithstanding these developments, philanthropy is a term coined only in the 1980s and "even today it is not a widely accepted or understood term in American academic life" (Katz, 1999, p. 74). As the noted philanthropy scholar Payton (1995, p. 3) contended, "there are few fields of such vast magnitude that have stimulated so little curiosity among scholars." Indeed, it is ironic that despite high levels of professionalization in the philanthropic sector in many parts of the world, very few people have any idea of what the concept means, its intellectual derivations, or more significantly, how it applies to various cultural, social, and political contexts in different parts of the world. Philanthropy and giving are often seen as the domain of professionals such as fundraisers, grant makers, and executive directors of foundations. It does not form a significant field of enquiry in its own right.

Two consequences flow from this context. First, the field is seen to have narrow intellectual horizons. Where philanthropy is conceptualized in terms of human services, it tends to be limited to the field of social work with a focus on helping the disadvantaged. Where it is seen as part of the nonprofit world, it focuses on legal and institutional issues, on distinctions between "public" and "private" institutions, relations with government financing and activities, as well as the modern infrastructure relating therein. The study of philanthropy comes from other fields such as anthropology, economic history, economics, sociology, political science, public administration, and business management, all of which come with their own conceptual frameworks. Second, scholarship in this field is inevitably more practical than academic. The limited number of academic studies on the subject are not of a reflective scholarly character, but rather written to stimulate operational practice in the nonprofit sector. This also leads it to be defined almost exclusively in Western or Euro-American terms, thereby ignoring the rich traditions of giving in multicultural contexts in different parts of the world.

The result is that the literature tends to take the form of "how to do" manuals; or, where there is the retention of some veneer of the academy, it tends to be narrowly descriptive and/or empiricist. Either way, it does not allow for comparative reflections that would enable the identification and development of common analytic themes. Despite this negative assessment of philanthropic literature, a review does permit, in both a positive and negative sense, the conceptualization of theoretical levers or hypotheses, based on widely held assumptions, which may serve as investigative tools to enable a detailed analysis of processes of giving in South Africa. 
Three assumptions implicit in the philanthropy literature are tested in this paper through the quantitative investigation of giving in South Africa. First is the assumption that giving is an act generally undertaken by richer, more resourced sections of the community and directed toward less resourced sectors. Donati (2003), for instance, suggests that giving is more likely to come from people who have been financially successful, and those who have retired and accumulated wealth and assets. Olson (1965), Becker (1974), and Wright (2001) argue that giving is primarily driven by psychosocial motives - to gain status, prestige, and respect-all of which can be achieved by the wealthy that have surplus resources to dispense. Similarly, Brown et al. (2000) associate philanthropy with the benevolence and paternalism of the wealthy elite.

This assumption is also implicit in a set of philanthropy literature concerned with its undemocratic consequences. Salamon (1995), for instance, argues that the philanthropy sector tends to be shaped by the needs of wealthy individuals rather than the community as a whole. Consequently, some services desired by the affluent such as art and music may receive priority, while others required by the poor are neglected. Since such private donations are tax-deductible, "they have the effect not only of allocating private expenditures, but also of allocating foregone public revenues as well, though without the benefit of any public decision process" (Salamon, 1995, p. 47). This leads to an undemocratic situation where the rich are able to exercise control over their resources, while the poor become dependent on charity (Salamon, 1995). Implicit in all this literature is that giving is an act undertaken by the rich and wealthy. But is this true in developing world contexts?

Anyone familiar with countries of the South would recognize that there are numerous collective instruments within marginalized communities that are either part of traditional or indigenous life (Moyo, 2004), or have been developed to assist with the harsh economic circumstances in which people find themselves. Much of this is captured in the sociological and anthropological literature on the southern African region. For example, a great deal has been written on the role of stokvels (rotating credit circles), which are a well-known self-help phenomenon in South Africa that assists and allows poor people to survive their economic circumstances (Dandala and Moroka, 1990; Lukhele, 1990; Verheof, 2002). Stokvels are community-based financial arrangements which have been used for different purposes, either personal/individual (buying furniture that would have been otherwise unaffordable or paying for lobola or bride-price) or broader developmental uses for the community. Burial societies are another well-documented expression of the intersection of economic necessity and associational giving traditions. Funeral costs are generally high in Black communities because of the belief that burial has to take place in the land of the ancestors (commonly the area where the person was born) (Dandala and Moroka, 1990). Burial societies have also assumed greater importance in the lives of poor people in the context of HIV/AIDS, increasing fluidity and flexibility of borders due to high unemployment, and conflict in the region as a whole. For example, there are a number of burial societies formed by 
Zimbabwean refugees living in South Africa who pool money and other resources in order to transport the dead from South Africa home to Zimbabwe (Moyo, 2004).

This literature, the results of The Johns Hopkins study on the nonprofit sector (Swilling and Russell, 2001), and anecdotal evidence, suggest that giving in South Africa must not be conceived in a unilinear direction from rich to poor communities. Indeed, giving must be assumed to occur in both the worlds of rich and poor, both separately and as points of intersection. What needs to be investigated is the extent thereof, and whether patterns of giving and the motivations that underlie it differ in, and between, these respective communities. A study of corporate social investment in South Africa in 2000 concluded that the levels of social investment per capita by the country's corporate sector was on a par with, if not higher than, their North American counterparts (Rockey, 2000). The South African study on the nonprofit sector-part of the global study of the sector coordinated by the Centre for Civil Society at the Johns Hopkins University-supported the conclusion that significant social investments are made by South African corporates when it estimated that some R3 billion per annum is made available in this regard (Swilling and Russell, 2001, p. 36). ${ }^{6}$ Further, the study demonstrated that of the 98,920 civil society organizations in the country in 1998, some 53\% were informal organizations located in and managed by the country's most marginalized and underresourced communities themselves (Swilling and Russell, 2001, p. 20). This suggests that there is a significant flow of resources within marginalized and poor communities toward poverty alleviation.

A second assumption in the philanthropy literature is its implicit portrayal of giving as a voluntary act inspired by generosity, religious conviction, or other more altruistic motives. Implicit in this depiction is the assumption that the nuclear family is the basic unit of all societies. Yet we do know that in large parts of the world, and in the developing world in particular, nuclear families are simply a subcomponent of extended families. Patterns of obligation therefore occur in ways fundamentally different to those of the industrialized western world. Family and informal networks are highly personalized and giving is more influenced by specific identity categories such as relatives, friend, and neighbors. While there may well be altruistic or selfish motives, such giving is not motivated by profit, is not enforced by law, and is not entirely voluntary. And more often than not this informal system of sharing and caring is taken for granted (Report of the Wolfden Committee, 1997).

The Report of the Wolfden Committee (1997, pp. 22-23) distinguishes among three categories of informal sharing and caring: provision of care for the young and the weak, especially the sick, the disabled, and the elderly; the transfer of material resources, particularly between members of a family, from those with a surplus to those with a deficit; and, the provision of advice and psychological support, e.g., from the experienced to the inexperienced.

${ }^{6}$ Rand-Dollar (US) exchange rate: R6.50 $=\$ 1.00$. 
None of the three categories are regarded as philanthropy or charity by the giver when the recipient is a member of their extended family, group, or community. Rather, these actions are conceptualized in terms of mutual obligation, part of the responsibility of belonging to an extended family, group, or community. An underlying reciprocity is understood, even as givers do not literally expect gifts to be directly returned.

Hyden (1983, p. 82) captured this experience by coining the term the "economy of affection" which refers to "a network of support, communications, and interactions amongst structurally defined groups connected by blood, kin, community, and other affinities for example, religion." These, he informs us, tend to be ad hoc and informal, rather than regular and formalized. The economy of affection points us to an enormous amount of what would be considered giving in a western context, but would in our circumstances simply be seen as patterns of obligation and duty similar to those undertaken within the nuclear family. It is important to be aware of this so that it is not only interrogated in this study, but also reflected in a comparative context.

Third, the philanthropy literature suggests that a great deal of giving is inspired by religious belief. Giving is seen to be associated with a deep sense of responsibility, duty, and commitment in order to realize spiritual salvation. For Christians charity or "love in action," for instance, is one of three basic virtues, the other two being faith and hope. The spirit of giving infuses Christian scriptures and is succinctly captured in the New Testament adage that it is "better to give than to receive." All Christians, according to the Old Testament, are expected to give $10 \%$ of their monthly income in the form of a tithe to their church. A tithe is an obligatory form of giving mandated by the Bible. In addition, many Christians also engage in voluntary giving for a variety of social and humanitarian causes (Chetty, 2004).

Contributing to charity is one of the basic tenets of Islam. All Muslims are obliged to contribute $2.5 \%$ of their yearly income toward community improvement, especially supporting those who are indigent. This is called Zakaat and is intended to address socioeconomic problems among Muslims. Among Muslim nations such contributions are regulated by the state and institutions called the Baitul Mal were responsible for collecting and allocating this compulsory charity. There are also other forms of giving among Muslims, which also support causes outside the community (Khan, 2004).

The principles of generosity, hospitality, philanthropy, and charity are also important hallmarks of Hinduism. These cannot be read easily from religious texts since Hindu philosophy is a complex body of thought that can be interpreted in multiple ways. Nevertheless, all interpretations would concur that charity is encouraged, specifically for those not engaged in devotional service. Altruistic and humanitarian activities are seen as means to develop selfless qualities, which brings one closer to God (Sookraj, 2004). 
Finally, giving in Judaism is defined by the term Tzedalah, which means righteousness and refers to the ancient religious obligation to provide for the indigent, both Jews and non-Jews. The Torah — the first written law-provides the written instructions as to how to carry this out. One tension, which flows from rival schools of Jewish religious philosophy, is between those who give only to Jews, and others who also invest in the non-Jewish poor of countries which host the Diaspora. The purpose of Tzedelah, however, is to reinforce cultural, religious, and ethnic identity, and to provide protection from external threat (Tobin, 2000).

As a result, then, religious leaders of all faiths cultivate the habit of charity with the result that their adherents tend to give more time and money to both faith-based and secular initiatives (Independent Sector, 2002, p. 7). Religious congregations in the United States, for instance, collected \$81.2 million in 1996. Is a similar pattern of religiously inspired giving evident in South Africa? After all South Africa has a high level of religiosity. Almost the whole spectrum of world religions as well as indigenous alternatives has adherents in the country. South Africa is a multireligious society, where freedom of worship and religion are constitutionally protected. Although Christianity is dominant, Islam, Judaism, and Hinduism are also active religions in South Africa. About $84 \%$ of the South African population belongs to the Christian faith, $0.2 \%$ adheres to Judaism, and $1.5 \%$ is Hindus and Muslims, respectively (Bower, 2004, p. 45). The fastest growing churches are the African Independent Churches, whose origins lie within Africa rather than imposed from outside. According to the 2001 census about $40 \%$ of the population belong to a charismatic church, and more specifically, 10 million belong to African Independent Churches, such as the Zion Christian Church (Philp et al., 2004). It has been estimated that more than $50 \%$ of the congregations of the charismatic churches were "tithing a full $10 \%$ of their often sizeable professional incomes" (Philp et al., 2004, p. 24). How effective are these religious institutions in mobilizing individual and public resources? What are the motivations that underlie this mobilization of resources and what are its net effects? These questions need to be investigated in the South African context.

The foregoing assumptions serve as intellectual lenses to investigate and reflect upon contemporary patterns of giving in South Africa. It is not an exhaustive analysis of the philanthropic literature. Rather it is a set of core assumptions that speak to the reality of structural dynamics in the South African sociopolitical setting, and thus serves as an investigative tool that enables a probe into patterns of individual giving.

\section{CONTREMPORARY PATTERNS OF GIVING IN SOUTH AFRICA}

The importance of giving and philanthropy to South African history and the development of national character have been largely ignored by academics, policymakers, and other key stakeholders. This may be because giving and philanthropy 
are likely to be associated with elitist and class-based connotations of charity for the poor and disadvantaged. This is a grave misconception. First, the range of activities assumed to be contained within this understanding of giving and philanthropy is too narrow and precludes an appreciation of the distinctive contribution they make to the life of the society. Second, it focuses on the act and ignores the impulse - the private assumption of public responsibilities - thus missing critical questions about the nature and direction of development in the country. At base, this relates to the role of government versus the socially conscious actions of individuals, communities, and the greater society.

There is little definitional coherence in developmental circles on the concept of philanthropy. This is particularly true in South Africa where data available on giving is patchy and weak. There is no local equivalent to Giving USA: The Annual Report on Philanthropy. Figures published in different studies relating to giving of different kinds are neither comprehensive nor detailed, and are often based on vague estimates. Semantic or conceptual difficulties notwithstanding, there is no doubt that giving and philanthropy are deeply rooted in South African tradition and culture, touch the country's citizens in countless ways, and provide significant resources for some of the nation's most important developmental activities.

This is evident in a number of initiatives such as the Daily News Milk Fund, Red Nose Day, Casual Day, and the activities of the ubiquitous Community Chest. At an institutional level there exist professional vehicles for giving, such as highprofile charitable organizations like the Nelson Mandela Children's Fund and the Desmond Tutu Peace and Education Trust. But there is also a rich variety of "invisible" giving, which operate in different multicultural contexts for community and individual-based giving (Maluccio and Haddad, 2000). The Social Giving survey, reported below, reveals both forms of giving by South Africans.

\section{Individual Giving: Money, Goods, and Time}

A useful starting point for a critical examination of giving in South Africa is the observation that South Africa is a giving society, the title given to the report of the first ever representative study of giving in the country (Everatt and Solanki, 2004). South Africa is richly resourced with a diverse and multicultural spectrum of giving behaviors, which are commonplace in everyday life. The spectrum of giving behaviors is so diverse in shape and form that it contradicts many of the basic assumptions of the philanthropic literature, which locate the act of giving primarily in the domain of the wealthy and powerful.

The Social Giving survey recognizes the heterogeneity of South African society, but argues that "giving" supersedes this diversity and is common to the vast majority of citizens. South Africa emerges from the survey as a generous and socially conscious country: over half of the respondents $(54 \%)$ gave money to charities or other causes, a third (31\%) gave food or goods to charities or other 
Table I. Reported Giving Behavior (October 2003)

\begin{tabular}{lc}
\hline \multicolumn{1}{c}{ Thinking about the last month, have you personally } & $\%$ Yes \\
\hline Given money to a charity or other cause? & 54 \\
Given goods, food, or clothes to a charity or other cause? & 31 \\
Given time (i.e., volunteered) to a charity or other cause? & 17 \\
Given money to a beggar/street child/someone asking for help? & 45 \\
Given food, goods, or time to a beggar/street child/someone asking for help? & 45 \\
\hline
\end{tabular}

causes, while slightly less than a fifth (17\%) volunteered time for a charity or cause. In addition to giving to formalized institutions or causes, slightly less than half of respondents told us they gave money and/or goods (45\%, respectively) not to formal charities but directly to the poor-street children, people begging on the street, and so on (Table I).

A key objective of the survey was to measure the level of resource mobilization for charity and poverty alleviation occurring among South Africans (within the limitations of survey research). Respondents were asked if they had given money, time, or goods to either a charity or organization or directly to a poor person in need, in the month prior to being interviewed (October 2003). For respondents who had done so, we asked how much money or time they had given, or what type of goods. Three items were quantified: money given to a charity, cause, or organization; money given directly to the poor; and the amount of time given (volunteering). Table II provides the mean or average (in the middle column) across all respondents in the sample - not merely the mean of those who gave-while the right-hand column extrapolates this to the population as a whole.

Table II suggests that each month South Africans give an average of R27 to organizations, R6.60 directly to poor people, or R33.60 in all. (Among people who give money, the mean is of course higher, at R44 per month.) If we extrapolate this to all South Africans aged 18 and above (reflecting our sample), R921m is given by South Africans per month to social causes. The data in Table II also show that South Africans, on average, volunteer $1.9 \mathrm{~h}$ per month for charities and organizations. This amounts to a total of $52 \mathrm{~m}$ person $\mathrm{h}$ per month.

Analyzing these across demographic categories, see Table III, we find on average that men gave more money than women, both to organizations and directly to the poor. Women, on the other hand, gave more time than men; when giving,

Table II. Total Money and Time Given (All Respondents, October 2003)

\begin{tabular}{lll}
\hline \multicolumn{1}{c}{ Item } & $\begin{array}{c}\text { Sample } \\
\text { mean }\end{array}$ & \multicolumn{1}{c}{$\begin{array}{c}\text { National } \\
\text { extrapolation }\end{array}$} \\
\hline Money given to a charity/cause/organization & R27 & R740,797,000 \\
Money given directly to the poor & R6.60 & R181,084,000 \\
Time given to a charity/cause/organization & $1.9 \mathrm{~h}$ & $52,000,000$ (2m days) \\
Total money given (formal and informal) & R33.60 & R921,880,000 \\
\hline
\end{tabular}


Table III. Total Giving by Race and Sex (All Respondents, October 2003)

\begin{tabular}{lcccc}
\hline & $\begin{array}{c}\text { Average money } \\
\text { to charity/org. } \\
\text { (R per month) }\end{array}$ & $\begin{array}{c}\text { Average money to } \\
\text { beggar/street child/etc. } \\
\text { (R per month) }\end{array}$ & $\begin{array}{c}\text { Total average } \\
\text { money giving } \\
\text { (R per month) }\end{array}$ & $\begin{array}{c}\text { Average time } \\
\text { volunteered } \\
\text { (h per month) }\end{array}$ \\
\hline All & 27 & 7 & 34 & 1.9 \\
Sex & & & & \\
$\quad$ Male & 29 & 7 & 36 & 1.7 \\
$\quad$ Female & 26 & 6 & 32 & 2.2 \\
Race & 16 & 5 & 21 & 2.2 \\
$\quad$ African & 58 & 22 & 80 & 2.1 \\
Indian & 62 & 5 & 67 & 1.1 \\
Coloured & 80 & 17 & 97 & 0.6 \\
$\quad$ White & & & & \\
\hline
\end{tabular}

women were more likely to give goods than cash. Looking at race we find that on average White respondents gave more money to organizations than others, reflecting the economic status given to them under apartheid; where White respondents gave an average of R80 to organizations, this dropped to R17 given directly to poor people begging on the street. But while Whites tend to give money, they give less time-White respondents on average volunteered for just $0.6 \mathrm{~h}$ in the month before being interviewed. The close correlation between education and economic status is reflected in the finding that those with no or low formal education gave lower amounts of money than those with higher levels of education.

Volunteerism is another common practice among South Africans, albeit one that more often than not goes largely unnoticed-perhaps because the poor make up the bulk of volunteers. Giving in the South African context must be conceptualized as involving time and not simply the exchange of financial resources. The study of the nonprofit sector in South Africa found that the area had a high number of volunteers: more than 1.5 million volunteers actively contributed their time and energy to the sector, equivalent to 316,991 full-time jobs (Swilling and Russell, 2001, pp. 17-18). It is said to account for $49 \%$ of the total work force of volunteers. This figure is not surprising given that $53 \%$ of this sector is made up of community-based organizations, which do rely on volunteers to fulfil staffing needs. According to the present study, Black people volunteered more time (70\%) than Whites (30\%); and males volunteered slightly more (51\%) than females $(49 \%)$.

In all, $17 \%$ of respondents volunteered time in the month before being interviewed; during that month, they gave an average of $11 \mathrm{~h}$ each. (The average across the entire sample-including those who did not volunteer-is $1.9 \mathrm{~h}$ ). This extrapolates to some 4.6 million people volunteering their time (considerably higher than the figure given in the nonprofit survey [Swilling and Russell, 2001], although it derived its figures in a very different manner).

The most dramatic manifestation of giving by the poor, particularly through the provision of time, is the proliferation of HIV/AIDS home-based care initiatives, 
Table IV. Total Giving by Education, Province, and Socioeconomic Status (October 2003)

\begin{tabular}{lcccc}
\hline & $\begin{array}{c}\text { Average money } \\
\text { to charity/org. } \\
\text { (R per month) }\end{array}$ & $\begin{array}{c}\text { Average money to } \\
\text { beggar/street child/etc. } \\
\text { (R per month) }\end{array}$ & $\begin{array}{c}\text { Total average } \\
\text { money giving } \\
\text { (R per month) }\end{array}$ & $\begin{array}{c}\text { Average time } \\
\text { volunteered } \\
\text { (h per month) }\end{array}$ \\
\hline All & 27 & 7 & 34 & 1.9 \\
Province & 34 & & & \\
Eastern Cape & 26 & 8 & 41 & 5.2 \\
Free State & 21 & 11 & 37 & 0.6 \\
Gauteng & 19 & 6 & 28 & 1.5 \\
KwaZulu-Natal & 25 & 6 & 25 & 1.1 \\
Mpumalanga & 23 & 7 & 32 & 0.2 \\
Northern Cape & 17 & 3 & 26 & 1.0 \\
Limpopo & 18 & 6 & 23 & 3.6 \\
North West & 67 & 5 & 23 & 0.7 \\
Western Cape & 29 & 7 & 74 & 1.3 \\
Socioeconomic status & SES) & & 37 & 1.8 \\
High SES & 17 & 7 & 20 & 2.8 \\
Low SES & 29 & 3 & & \\
\hline
\end{tabular}

stokvels, and burial societies (Moyo, 2004), all of which enable poor people to survive the ravages of their economic and health circumstances. This kind of giving behavior does not fit within the strict definition of volunteering as "the willing provision of unpaid labor" (Jedlicka, 1990, p. 4). Most analyses (which originate in the North) restrict the concept to volunteering within the context of a formal organization. The provision of unpaid work to informal social caring and neighborly support is not usually considered to be volunteering, although it is clearly an essential requisite to economic survival and to the well-being of the communities and civic life in general. As shown in the bottom two rows of Table IV, we find again that those with low socioeconomic status gave less money and more time, reversed among those with high socioeconomic status. Analyzed by province, we find that the poorer provinces tend to have the highest levels of volunteering (Eastern Cape followed by Limpopo); but the wealthier provinces are not necessarily those giving most money (Gauteng respondents, for example, gave less money and less time than respondents from the Eastern Cape).

Broadly speaking, there is an inverse relationship between giving money and time- - those in privileged economic positions in society tend to give money, while those lacking money give more time. African respondents on average gave the lowest amounts of money to organizations (R16) or individuals (R21), but the largest amount of time $(2.2 \mathrm{~h})$. Indian respondents were the exception, giving both money and time.

In all, $77 \%$ of respondents told us they gave money (any amount) directly to charities, causes, or organizations or to poor people directly. Measured across the entire sample, the average respondent gave R33.60. As a nationally representative sample, we can extrapolate these findings to the population as a whole. According to Census 2001, there are 27,436,917 South Africans aged 18 and above. If each 
of those people gave R44 to a charity or directly to the poor, then South African citizens mobilized slightly less than R930m (approximately $\$ 155$ million) in an average month for development and antipoverty work. From one perspective, this is a massive amount of money. However, it should be seen in context: Census 2001 found that the total monthly income for the working age population (i.e., excluding those aged 65 and over who we have included in our sample) was R42 billion. The survey results suggest that $2.2 \%$ of this is given away to organizations or to the poor.

The survey found that poor and nonpoor respondents were equally likely to have given in the month prior to being interviewed. Whereas better-off respondents gave money, those who could not afford to do so offered their time-indicating that there is a need to look beyond the state for a full understanding of propoor and developmental resource flows. Giving remained high even among respondents scoring high on standard survey measures of alienation and anomie, $92 \%$ of whom had given in the month prior to being interviewed. With more than 9 in 10 respondents actively giving, it can be concluded that giving seems to be ingrained in respondents.

The survey data demonstrate that poverty does not necessarily serve as a deterrent to giving. Where there is a lack of money, people then tend to give time. Volunteering can thus be seen as the giving strategy of those without financial resources. It follows then that people in rural areas are more likely to volunteer time than their urban counterparts. Giving is not the domain of the wealthy: it is part of everyday life for all South Africans, rich and poor alike.

\section{Giving in the Extended Family}

Giving behaviors in South Africa often operate within the institutional parameters of the extended family. ${ }^{7}$ Giving within extended families represents an interesting challenge to the existing literature on philanthropy. A significant proportion of the African population is socially organized around the extended family with the result that their patterns of familial obligation and reciprocity extend well beyond the nuclear family unit. Giving within extended families is often not conceived as philanthropy or charity, because it is informed by patterns of obligation very similar to those occurring within the nuclear family. The Social Giving survey found that a third (34\%) of respondents regarded giving within the extended family as a duty or obligation. Over half of respondents $(55 \%)$ felt that philanthropy began when they paid for children outside the nuclear family (Table V).

Just over half (55\%) of respondents said they had given money, goods, food, or other items to members of their family not living in their household in the

\footnotetext{
${ }^{7}$ See Hyden (1983) for perspectives on giving within extended families in an African context and the role that an "economy of affection" plays in economic development in Africa.
} 
Table V. Giving to Nonhousehold Family Members by Province, Sex, Race, and SES (All

Respondents, October 2003)

\begin{tabular}{lc}
\hline & \% giving \\
\hline All & 55 \\
Province & \\
Eastern Cape & 75 \\
Free State & 57 \\
Gauteng & 63 \\
KwaZulu-Natal & 44 \\
Mpumalanga & 38 \\
Northern Cape & 52 \\
Limpopo & 73 \\
North West & 47 \\
Western Cape & 34 \\
Sex & \\
Male & 53 \\
Female & 58 \\
Race & \\
African & 59 \\
Indian & 58 \\
Coloured & 42 \\
White & 39 \\
Socioeconomic status (SES) & \\
High SES & 55 \\
Low SES & 58 \\
\hline
\end{tabular}

month before being interviewed. Money was most commonly mentioned, followed by food and drink, and clothing. Women (58\%) were more likely than men $(53 \%)$ to give money, goods, or other items to nonhousehold family members, although when men did so they were more likely to give money $(75 \%)$ than women $(66 \%)$. On other items, such as food and drink, clothing, medical supplies, and so on, women predominated. Helping nonhousehold family members differs considerably by race: as shown in Table V, African (59\%) and Indian (58\%) respondents were considerably more likely to do so than coloured (42\%) or White (39\%) respondents. It was also influenced by religion, with two-thirds $(64 \%)$ of non-Christians helping nonfamily members, dipping slightly among Christians.

Taking the point further, a third of respondents with children aged below 18 told us their household included children who were not the children of the head of the household. We tested all respondents' attitudes to this, and found that a third (34\%) felt that paying for their own children was their duty, paying for the children of relatives was giving - but over half $(55 \%)$ felt that duty extended to paying for their own and relatives' children; giving began where they paid for children outside the family. These answers reflect a very different set of perspectives on the notion of giving, where it begins and ends, and what it covers.

The pattern that emerges from the survey is that giving is higher among respondents from the poorest provinces, notably the Eastern Cape and Limpopo, 
among women, among African and Indian respondents, and among those in the low socioeconomic status category. Giving, it seems, is a considerable distance from traditional notions of philanthropy.

These findings raise significant questions about the giving behaviors practiced within families. What does giving mean within such a context? Many people do not regard the considerable amounts that they give to extended families as giving. An underlying reciprocity is understood in terms of mutual obligation and the responsibility of belonging to an extended family (even as givers do not expect their gifts to be returned). The following questions must be asked: Is a family member giving when s/he is taking care of her/his family and extended family? How much of this type of "giving" is about social expectation and how much of it is about the philanthropic impulse? Where does giving begin and end within such a context of duty and obligation? The Social Giving survey data suggest that developing societies, with their very different social and familial behaviors and traditions, seriously challenge existing definitions and premises prevailing in the philanthropic literature, which are overwhelmingly located in the experience of developed countries.

\section{Faith-Based Giving}

Localized informal giving (as illustrated above) is counterbalanced by the practice of other kinds of giving that are more formal and institutionalized in nature. One immediately visible example is that of faith-based giving. South Africa is a religiously active country. Religion emerged from the Social Giving survey as the preeminent factor where social giving is concerned. Among respondents who said they belonged to a religion or faith $-89 \%$ of respondents - an average of $96 \%$ gave money, goods, or services in the month prior to being interviewed. This dropped to $80 \%$ among atheists.

The influence of religion on giving was functional as well as ethical. Among respondents with a religion or faith, $89 \%$ said their religion requires them to make a regular payment or contribution (such as Zakaat among Muslims, tithe payments among Christians, and so on); four-fifths (84\%) make such payments. Respondents with a faith or religion tended to believe (correctly, as it turned out) that "Religious people give more to the poor than nonreligious people": while a third (33\%) rejected the notion, $43 \%$ agreed or strongly agreed.

Intriguingly, respondents with a faith or religion ( $89 \%$ of the sample) were divided as to whether or not religions use giving as a way of converting people: a third $(33 \%)$ rejected the notion, a fifth (22\%) neither agreed nor disagreed, while the remaining 55\% agreed that giving is a recruitment tool.

Analyzing the mean scores of giving we find that atheists who gave money (to charities and to the poor), on average gave less than Christians, while nonChristian respondents gave the highest average amount (R54 per respondent who 
gave). However, atheists were likely to give more time, averaging $14 \mathrm{~h}$ (among those who volunteered) compared with $12 \mathrm{~h}$ among non-Christians and $11 \mathrm{~h}$ among Christians.

The Social Giving survey results vividly reflect the influence of religion. A quarter of those without a faith or religion gave money in the month prior to being interviewed, rising to $42 \%$ of those who refused to tell us whether or not they had a religion or faith. This rises to over half (52\%) of non-Christian respondents, and again to include $60 \%$ of Christian respondents.

\section{The "Giving" Agenda}

The Social Giving survey asked respondents what they thought was "the most deserving cause that you would support if you could?" This was an open-ended question where respondents could give any answer they wish; answers were later categorized and given numeric codes. It was phrased so as to allow all respondents to tell us what they would support regardless of whether or not they currently either do so or are in a position to do so.

Answers were dominated by three categories: respondents believed the most deserving causes were those associated with children or youth $(22 \%)$, followed by HIV/AIDS $(21 \%)$ and "the poor" $(20 \%)$. These were followed by a set of smaller categories, including people with disabilities $(8 \%)$ and the elderly (5\%). It is notable that $2 \%$ of respondents believed that their preferred political party was the most deserving cause, perhaps reflecting how recently South Africa began normalizing and the ongoing importance of politics in many lives. It would be interesting to know if political parties feature in similar surveys in other countries. One percent of respondents were sufficiently cynical to say "nothing" was a sufficiently deserving cause. The "other" category included a wide-ranging set of answers including animal welfare and environmental concerns.

The high scores - for children and youth, HIV/AIDS, and poverty-suggest that respondents have a progressive and propoor understanding of South Africa and societal priorities.

\section{CONCLUSION}

It is evident that there is a great deal of giving occurring in South Africa. However, an important question arises: Can giving and philanthropy actually address the issue of structural change in society and make a difference to the lives of people? Philanthropic giving has often been accused of not challenging the status quo. Corporate giving could be seen in this light: commentators might accuse the sector of colluding with the forces of inequality that ultimately reinforce a fundamentally unjust system. It is worth recalling the oft-quoted words of Martin Luther King: "Philanthropy may be commendable, but it must not overlook the circumstances of economic injustice that make philanthropy necessary" (http://quoationspage.co). 
Ultimately, contemporary patterns of giving in South Africa tend to reinforce some findings of the international philanthropic literature, but challenge others. They reinforce the findings that suggest, for example, that religion is a driving force in inspiring and organizing giving. But it challenges other findings. For instance, it demonstrates that giving occurs in both rich and poor communities: in fact, giving is more common among the poor than the rich, even though the latter (predictably) give greater amounts. It also adds rich empirical detail to the giving process by exposing giving processes within extended families and how these are conditioned by patterns of obligation rather than pure voluntarism.

\section{REFERENCES}

Becker, G. S. (1974). A theory of social interactions. Journal of Political Economy 82, 1063-1093.

Bezuidenhout, A., et al. (2003). A Political Economy of Corporate Social and Environmental Responsibility in South Africa. Sociology of Work Unit, University of Witwatersrand, Johannesburg, South Africa.

Bower, C. (2004, December 24). Spread the truth, not the word. Mail and Guardian, p. 45.

Brown, K. M., Kenny, S., and Turner, B. S. (2000). Rhetorics of Welfar-Uncertainty, Choice, and Voluntary Associations. Macmillan, London.

Chetty, I. (2004). Giving in the Christian community. Paper presented at Religious Giving Workshop, September 20. University of KwaZulu-Natal, Durban.

Dandala, H., and Moroka, K. (1990). Burial Societies. Skotaville, Johannesburg, South Africa.

Donati, P. (2003). Giving and social relations: The culture of free giving and its differentiation today. International Review of Sociology 13, 243-272.

Du Toit, C. (2001). CSI-A SAGA status report. In: The Corporate Social Handbook. Trialogue, Cape Town, South Africa.

Estes, R. J. (1998). Emerging Chinese foundations: The role of private philanthropy in the new China. Nonprofit Sector Research Fund, Working Paper Series. Aspen, Washington, DC.

Everatt, D., and Solanki, G. (2004). A Nation of Givers? Social Giving Among South Africans. Mimeo. Centre for Civil Society, University of KwaZulu-Natal, Durban, South Africa.

Hyden, G. (1983). No Shortcuts to Progress: African Development Management in Perspective. Heinemann, London.

Independent Sector (2002). Faith and Philanthropy-The Connection Between Charitable Behavior and Giving to Religion. Available online: www.independentsector.org

Jedlicka, A. (1990). Volunteerism and World Development. Praeger, New York.

Katz, S. N. (1999). Where did the serious study of Philanthropy come from, anyway? Nonprofit and Voluntary Sector Quarterly 28, 74-82.

Khan, S. (2004). The state of social giving amongst Muslims in South Africa. Paper Presented at Religious Giving Workshop, September 20. University of KwaZulu-Natal, Durban.

Lukhele, A. K. (1990). Stokvels in South Africa: Informal Savings Schemes by Blacks for the Black Community. Amagi Books, Johannesburg, South Africa.

Maluccio, J., and Haddad, L. (2000). Social capital and household welfare in South Africa: Pathways of influence. Paper Presented at the Center for the Study of African Economics, April 9-10.

Moyo, B. (2004). Philanthropy in the 21st Century: Challenges and opportunities, a study of Southern Africa. Paper Presented at the Ford Foundation Retreat, Uganda, March 28-April 2.

Olson, M. (1965). The Logic of Collective Action. Harvard University Press, Cambridge, MA.

Payton, R. L. (1995). Philanthropy: Voluntary Action and the Public Good. Available online: www.paytonpapers.org

Philp, R., Ntshingila, F., Sukhraj, P., Gules, N., and van der Merwe, J. (2004, December 22). Glory hallelujah! Sunday Times [Johannesburg], pp. 24-25.

Report of the Committee of Inquiry into a Comprehensive System of Social Security for South Africa (2002). Department of Social Welfare and Development, Pretoria, South Africa. 
Report of the Wolfenden Committee (1977). The Future of Voluntary Organisations, London.

Rockey, V. (2000). The CSI Handbook. Trialogue, Johannesburg, South Africa.

Salamon, L. M. (1995). Partners in Public Service. The Johns Hopkins University Press, Baltimore.

Sookraj, R. (2004). Social giving report back: The Hindu Perspective. In Paper Presented at Religious Giving Workshop, September 20. University of KwaZulu-Natal, Durban, South Africa.

Swilling, M., and Russell, B. (2001). The Size and Scope of the Nonprofit Sector in South Africa. Center for Civil Society, University of KwaZulu-Natal/Graduate School of Public and Development Management, University of the Witwatersrand, Johannesburg.

Tobin, G. A. (2000). The transition of communal values and behavior in Jewish philanthropy. Paper Presented at the Forum on Philanthropy, Public Policy, and the Economy. University of California, Los Angeles.

Verheof, G. (2002). Stokvels and economic development: The case of African women in South Africa (1930-1988). In: B. Lemrie, G. Campbell, and R. Pearson (eds.), Women and Credit: Researching the Past, Refiguring the Future. Berg, Oxford.

Wright, K. (2001). Generosity vs. altruism: Philanthropy and charity in the United States and United Kingdom. Voluntas 12(4), 399-416. 